\title{
The Entrepreneurship Characteristics in Relation to Improve the Performance of the Small-Scale Seaweed Entrepreneurs
}

\author{
Romansyah Sahabuddin \\ Teaching Staff at Management Study Program Human Resources Management Economy Faculty Makassar \\ State University Jln. Andi Pangeran Pettarani Kampus Gunungsari Baru Makassar, Province of South
} Sulawesi, 90222

\begin{abstract}
The purpose of this study was to obtain empirical evidence and find clarity about the impact of entrepreneurial characteristic related to achievement motivation and self efficacy as a latent variable exogenous to the entrepreneurial commitment as an intervening variable and its impact on the performance of seaweed entrepreneurs as an endogenous variable. The method used is survey research data collection techniques using questionnaires to determine the respondents assessment of the variables examined. The sample size of this study based on the technique of proportional cluster random sampling from the target population of small-scale seaweed entrepreneurs spread over ten districts of South Sulawesi province. Testing hypotheses using structural equation modeling analysis (SEM) based on the framework of the measurement model and the structural model of causal relationships between variables. Implication of this research is that the entrepreneurial commitment has contributed more dominant than the influence of achievement motivation and self-efficacy on seaweed entrepreneur's performance, either directly or indirectly through entrepreneurial commitment.
\end{abstract}

Keywords: Achievement Motivation, Self Efficacy, Entrepreneurial Commitment, Entrepreneurs Performance

\section{Introduction}

Less internalized personality values in the training activities can impact on a lack of real activities that can be done by the people, so the impact on a number of projects or programs the government has not shown significant results in which some of the projects implemented did not last long as expected.

Entrepreneurship developments through community empowerment through education and training programs are expected not only oriented toward mastery of the material and skills, but also strengthening the values of entrepreneurship-oriented personality, which is expected to build character dynamic and creative entrepreneurship.

A person-oriented entrepreneurship demonstrated by the nature or characteristics, such as: achievement motivation, persistence, and strong commitment, and tend to result in achievement or performance through the ability to produce creativity and innovation in ideas or new products. The low values entrepreneurship personalities such as achievement motivation, self efficacy, entrepreneurial commitment and entrepreneurial performance may have implications on the development of small businesses are less, as shown in Table 1 describes the population of small-scale seaweed entrepreneurs in 2008-2009 as follows.

Table 1. Number of Small and Medium Scale Seaweed Entrepreneurs in South Sulawesi Province Year 2008-2009

\begin{tabular}{rlrrrr}
\hline \multirow{2}{*}{ No. } & \multirow{2}{*}{ Regency } & \multicolumn{2}{l}{$\mathbf{2 0 0 8}$} & \multicolumn{3}{l}{$\mathbf{2 0 0 9}$} \\
\cline { 3 - 5 } Small & Medium & \multicolumn{1}{c}{ Small } & Medium \\
\hline 1. & Takalar & 3.562 & 645 & 3.135 & 700 \\
2. & Jeneponto & 4.550 & 453 & 3.415 & 530 \\
3, & Bantaeng & 2.543 & 545 & 1.730 & 585 \\
4. & Bulukumba & 1.154 & 350 & 950 & 350 \\
5. & Sinjai & 675 & 185 & 510 & 195 \\
6. & Selayar & 425 & 5 & 250 & 15 \\
7. & Pangkep & 520 & 77 & 450 & 85 \\
8. & Bone & 315 & 35 & 280 & 55 \\
9. & Wajo & 260 & 15 & 240 & 45 \\
10. & Luwu & 538 & 50 & 410 & 70 \\
\hline & & $\mathbf{1 4 . 5 4 2}$ & $\mathbf{2 . 3 6 0}$ & $\mathbf{1 1 . 3 7 0}$ & $\mathbf{2 . 6 3 0}$ \\
\hline
\end{tabular}

Sources: Department of Marine and Fisheries of South Sulawesi province, 2010 
The phenomenon that was found suggests that some small-scale seaweed entrepreneurs also pursue other business and some of them move on to other business or quit the activity. In addition, some small-scale seaweed entrepreneurs have switched to medium scale. Shift some seaweed businesses to other businesses as well as the stopping of activity shows that the low entrepreneurial commitment which could have implications on the poor performance of entrepreneurs. On the other hand entrepreneurial commitment which can be caused by low achievement motivation and low self-efficacy entrepreneurs. .

Another phenomenon that was found suggests that not all businesses seaweed optimally run business to improve its performance relating to the application of technology of cultivation, seed selection and production techniques and marketing activities are effective and efficient.

Based on the phenomena described above, the purpose of this study were: to obtain a picture of entrepreneurs based on the responses related to achievement motivation, self efficacy, entrepreneurial commitment and performance of small-scale seaweed entrepreneurs in South Sulawesi Province, as well as to obtain the results of the study the influence of achievement motivation and self efficacy against a entrepreneurial commitment, the influence of entrepreneurial commitment to the performance of small-scale seaweed entrepreneurs, the influence of achievement motivation and self efficacy on the performance of smallscale seaweed entrepreneurs, and the influence of achievement motivation and self-efficacy indirectly to the performance of small-scale seaweed entrepreneurs in South Sulawesi Province through a entrepreneurial commitment.

\section{Methods}

This research included in survey research, a method used to express the fact of a phenomenon by using a questionnaire as the primary data collection tool. Design studies are grouped into descriptive analysis and multivariate analysis using Structural Equation Modeling (SEM). The population in this study were all smallscale seaweed entrepreneurs in ten districts of South Sulawesi Province as much as 11370 (Office of Marine and Fisheries Agency of South Sulawesi Province, 2008). The samples used in this study is the small-scale seaweed entrepreneurs which has been operating in the 3 (three) years. The sampling is done using random cluster sampling method or the proportionate amount of the withdrawal of a random sample based on region or area sampling. Sampling techniques in the study area was conducted in two stages: first stage of determining the sample area, and the next stage to determine the respondent entrepreneurs of small-scale seaweed that exist in each region.

The determination of the number of samples is done by using the opinion of the provincial Slovin (Umar, 2001:78) the use of the above formula by Paguso, Garcia and quoted Guerrero Sevilla (Umar, 2001) showed a margin of error that can be used in population size. The large number of samples based on the formula Slovin research as much as 387 small-scale seaweed entrepreneurs. Further sampling in proportion to the spread in ten districts of South Sulawesi using proportional random sampling formula of Harun (1994).

\section{a. The validity of test instruments}

Instrument validity test performed to determine the validity of each item a question or statement on any variable. Test techniques used were correlation technique through the product-moment correlation coefficient of Pearson (Sugiyono, 2008:356). Coefficient $r$ significance test performed by t test (significance level 5\%). Testing decision is taken by comparing the value $\mathrm{t}$ count with the $\mathrm{T}$ Table. Valid question items disconnected them $t$ count value greater than $\mathrm{T}$ Table. Likewise it was decided not valid when $\mathrm{t}$ count equals to or smaller than T Table. An item said to be valid if a correlation coefficient greater than 0.3 .

\section{b. Reliability Test Instruments}

Reliability testing is done after all the items declared invalid and set aside items that are not valid. This test is intended to determine whether the instrument questions indicate the stability or consistency in explains certain symptoms of the respondents. Test technique used was halved correlation technique (Split-Half) by using the Spearman-Brown formula. Score intervals of successive items are summed to obtain a score of peculiar parts of an odd total. Similarly, interval sequential items are summed and even obtained a total score of evennumbered parts. Further parts of the total score correlated with the odd and even using the product moment correlation coefficient of Pearson. Further tests conducted by significance coefficient ri t test (significance level 5\%). An item said to be valid if a correlation coefficient greater than 0.7 (Sugiyono: 2008:359).

\section{c. Draft Analysis of Data}

Quantitative data were analyzed using descriptive analysis and analysis of Structural Equation Modeling (SEM). SEM analysis aims to assess: 1) the relationship between the independent variables (independent variables) and its influence, either simultaneously (together) or partial (respectively), to variable between (intervening variable), 2) the influence of variables on the variable bound (dependent variables); and 3) 
the influence of independent variables on dependent variable, either directly or indirectly through a variable between.

\section{d. Framework of thinking}

This study builds upon a theoretical constructive theory through the study of the link between the general theory (grand theory), theory or the theory of intermediate (middle theory), and the theory of the application (applied theory) as well as the results of previous research that refers to a constellation of relationships among latent variables assessed. Starting from this framework and theoretical basis, the research paradigm model that describes a constellation of relationships among latent variables, where variable Achievement Motivation and Self Efficacy positioned as independent variables (independent variables), entrepreneurial commitment as a variable between (intervening variable), and the performance of small-scale seaweed entrepreneurs as the dependent variable (dependent variable).

\section{e. Hypothesis Testing}

Research variables are divided into exogenous variables $(\xi)$ consists of Achievement Motivation variable $\left(\xi_{1}\right)$, and Self Efficacy $\left(\xi_{2}\right)$ and endogenous variables $(\eta)$ consists of a variable entrepreneurial commitment $\left(\eta_{1}\right)$ and Performance Entrepreneurs $\left(\eta_{2}\right)$. Complete skeleton model flow between variables based on the hypothesis proposed in this study appears in the following figure:

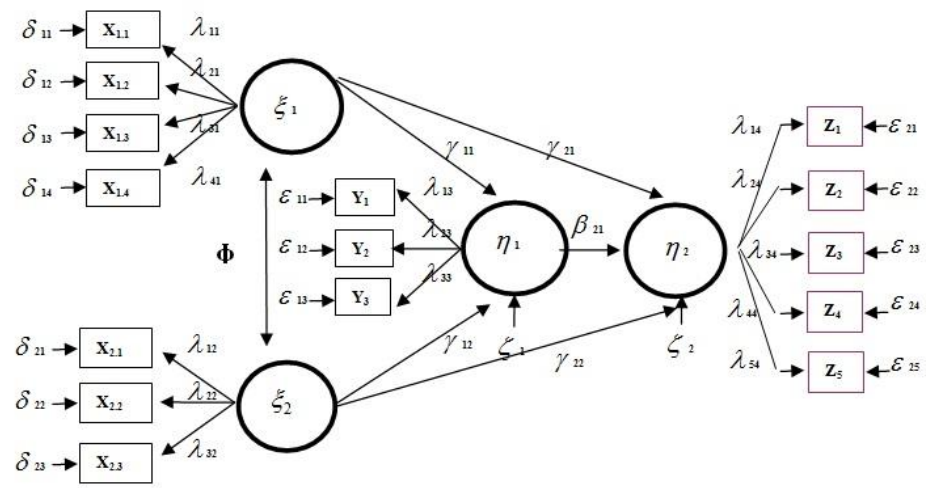

Figure 1 Structure Analysis of Variable Overall Research

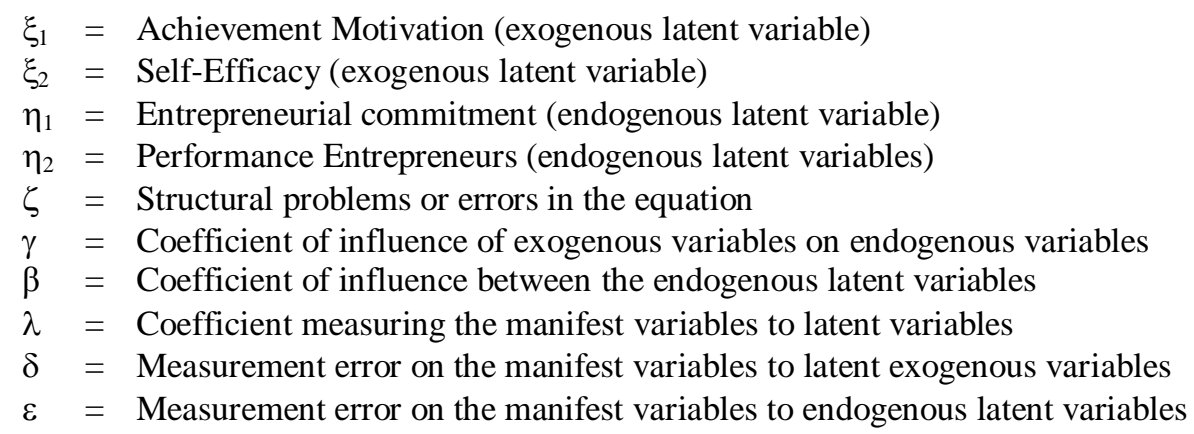

\section{Research Results}

\section{a. Description of Achievement Motivation Seaweed entrepreneurs}

Description of entrepreneurial achievement motivation is based on the total seaweed from the ordinal scoring on each of the entrepreneurs. Total score of achievement motivation which consists of 12 items on the 387 respondents amounted to 17 332. Determination of category is done by determining the quartiles limits; refer to the technical limits of the quartiles of Harun (1994: 128).

Table 2. The Entrepreneur's perception of Seaweed Based on Dimensions Each Latent Variables

\begin{tabular}{|l|c|c|c|}
\hline \multicolumn{1}{|c|}{ Dimensions } & Total Score & $\%$ & Category \\
\hline 1. Achievement Motivation & & & \\
- Achievement oriented & 4439 & 70,6 & Enough \\
- Future oriented & 4372 & 69,1 & Enough \\
- Likes challenges & 4166 & 64,7 & Enough \\
- Tough & 4355 & 68,8 & Enough \\
\hline
\end{tabular}


The Entrepreneurship Characteristics in Relation to Improve the Performance of the Small-Scale Seaweed

\begin{tabular}{|c|c|c|c|}
\hline Total & 17332 & $\overline{688,3}$ & Enough \\
\hline $\begin{array}{l}\text { 2. Self Efficacy } \\
\text { - Experience } \\
\text { - Planned behaviour } \\
\text { - Planned Achievement }\end{array}$ & $\begin{array}{l}2990 \\
2987 \\
3031\end{array}$ & $\begin{array}{l}71,6 \\
71,2 \\
72,3\end{array}$ & $\begin{array}{l}\text { Enough } \\
\text { Enough } \\
\text { Enough }\end{array}$ \\
\hline Total & 8981 & 71,7 & Enough \\
\hline $\begin{array}{l}\text { 3. Entrepreneurial Commitment } \\
\text { - Desire or Intention } \\
\text { - Discipline } \\
\text { - Determination }\end{array}$ & $\begin{array}{l}2774 \\
2890 \\
2990\end{array}$ & $\begin{array}{l}64,6 \\
68,3 \\
71,6\end{array}$ & $\begin{array}{l}\text { Enough } \\
\text { Enough } \\
\text { Enough } \\
\text { Enough }\end{array}$ \\
\hline Total & 8654 & 68,2 & Enough \\
\hline $\begin{array}{l}\text { 4. Entrpreneurs Performance } \\
\text { - Market development } \\
\text { - The ordering } \\
\text { - Job satisfaction } \\
\text { - Quality product } \\
\text { - Decent life }\end{array}$ & $\begin{array}{l}4505 \\
4301 \\
4162 \\
4309 \\
4328 \\
\end{array}$ & $\begin{array}{c}72 \\
67,6 \\
64,6 \\
67,8 \\
68,2 \\
\end{array}$ & $\begin{array}{l}\text { Enough } \\
\text { Enough } \\
\text { Enough } \\
\text { Enough } \\
\text { Enough }\end{array}$ \\
\hline Total & 21605 & 68 & Enough \\
\hline
\end{tabular}

Source: Results of Research, 2011. Data is processed

\section{b. Analysis of Structural Equation Modeling (SEM)}

Analysis of Structural Equation Modeling (SEM) using two approaches model, the measurement model and structural model.

\section{Measurement Model}

Measurement model describes the proportion of variance of each manifest variables (indicators) in each latent variable. Through the measurement model will be known where a significant indicator in the formation of the latent variables. In addition to testing the significance of the manifest variables, the measurement model can also be calculated construct reliability value that indicates whether a set of manifest variables that have a high degree of correspondence in the form of latent variables. The lower limit value of construct reliability is still acceptable limits are 0.7 and variance extracted values are still acceptable is 0.5 (Hair et al, 2006; 777-778).

The test results match the model SEM analysis showed: 1) the value of RMSEA (Root mean square error of approximation) for the studied model of 0.0339 so that the model has been obtained which meets the criteria expected value of RMSEA is small (less than 0.08), 2) GFI values for the studied model of 0.9598 indicates that the model meets the criteria is obtained, where the expected value of GFI close to $1(>0.90)$. The measurement results show the suitability of the model meets the criteria of absolute goodness of fit to the size of the RMSEA and GFI measures in accordance with the theoretical model. The value of construct reliability and variance extracted each indicator in each of the variables can be seen in the following table.

Table 3. Measurement of Latent Variable Model

\begin{tabular}{llllll}
\hline Variabel Laten & $\begin{array}{l}\text { Standardized } \\
\text { Loading }\end{array}$ & $\begin{array}{l}\mathrm{R}^{2}= \\
(\text { Standardized } \\
\text { Loading) }\end{array}$ & $\begin{array}{l}\text { Error } \\
\text { Variance }\end{array}$ & $\begin{array}{l}\text { Construct } \\
\text { Reliability }\end{array}$ & $\begin{array}{l}\text { Variance } \\
\text { Extracted }\end{array}$ \\
\hline Achievement motivation & 3,1128 & 2,4347 & 1.5653 & 0.8609 & 0.6087 \\
Self efficacy & 2,3969 & 1,9151 & 1,0849 & 0,8412 & 0,6384 \\
Entrepreneurial & 2,3796 & 1,8936 & 1,1064 & 0,8365 & 0,6312 \\
Commitment & 3,7937 & 2,8886 & 2,1114 & 0,8721 & 0,5777 \\
Entrepreneurs performance & & & & & \\
\hline T value $: \alpha(0,05), \mathrm{db}(\mathrm{n}-\mathrm{k}-1)$ & & & & \\
\hline
\end{tabular}

Source: Results of Research, 2011. Data is processed.

The table above shows that the value of reliability and construct all the indicators in each of the variables> 0.7 so that it can be said that the entire indicators have a degree of conformity in the shape of each latent variable. Furthermore the variance extracted value indicates the value of $>0.5$, so it can be said that each indicator has an opportunity to be represented in explaining latent variables. 
The Entrepreneurship Characteristics in Relation to Improve the Performance of the Small-Scale Seaweed

Structural Model

Structural model in this study largely made up of two structural equation functions, namely:

1. the function of the structural equation the influence of achievement motivation and self-efficacy toward entrepreneurial commitment. 2) The function of the structural equation the influence of achievement motivation, self efficacy and entrepreneurial commitment to the performance of small-scale seaweed entrepreneurs.

$\eta 1=\gamma 11 \xi 1 \gamma 12 \xi 2+1+\zeta$

$\eta 2=\gamma 21 \xi 1 \gamma 22 \xi 2+++\beta 21 \eta 1 \zeta 2$

SEM analysis results for the first hypothesis based on structural equation structural model are obtained: $\eta 1=$ $0.38 \xi 1 \xi 2+.5131+.4166$. The first hypothesis test results showed that simultaneous achievement motivation and self-efficacy affect entrepreneurial commitment to the contribution the influence of (R2): 58.34\%. Partially demonstrated achievement motivation and self-efficacy has a significant influence on entrepreneurial commitment

where the value $t$ count $>$ Ttable. More detail can be seen in the following table.

Table4.ContributionsInfluenceAchievementMotivationandSelfEfficacyAgainst Commitment Entrepreneurship

\begin{tabular}{cccrc}
\hline $\begin{array}{l}\text { Latent } \\
\text { Variables }\end{array}$ & $\begin{array}{l}\text { Path } \\
\text { Coefficients }\end{array}$ & Direct influence & $\begin{array}{l}\text { Indirect } \\
\text { influence }\end{array}$ & Total \\
\hline$\xi_{1}$ & 0,3800 & $14,44 \%$ & $8,79 \%$ & $23,23 \%$ \\
$\boldsymbol{\xi}_{2}$ & 0,5131 & $26,32 \%$ & $8,79 \%$ & $35,11 \%$ \\
\hline Simultaneous Influence $\left(\mathbf{R}^{2}\right)$ & & & $\mathbf{5 8 , 3 4 \%}$ \\
\hline
\end{tabular}

The results showed that achievement motivation built through success-oriented dimension, future oriented, risk-taking, and strong influence on the commitment-oriented entrepreneurship intention or desire, the discipline, and level of determination. Line proposed by Wig field et. al., (2002:1) that: a person who has demonstrated achievement motivation through behavior-oriented achievement through a strong desire to complete the task, perseverance, passion, and the quality of work in carrying out its activities. Further research Tang (2008) that self-efficacy affects the commitment. Someone who has a strong self-efficacy tend to make adjustments to the capabilities in planning a task, achievement, and career well and focused, allowing individuals to believe that he has a chance of achieving success or expected success.

While Bandura (2003:203) argues that: self-efficacy (self-efficacy) is the belief of individuals to a series of actions necessary to provide opportunities to achieve the desired performance level, and the basis for assessing a person's level of motivation and commitment.

The results Fortune et. al. (2005) found that achievement motivation and self-efficacy has a strong influence on one's commitment. In line with Boekaerts et. al., (2002) suggests the importance of self efficacy as additional factors other than achievement motivation in the formation of commitments. Someone who has a strong motivation can be caused by the presence of self-efficacy that confidences in the capabilities of the opportunity to succeed that have an impact on one's commitment in running the business. To test the second hypothesis, the influence of entrepreneurial commitment to the performance of small-scale seaweed entrepreneurs in South Sulawesi province refers to the line equation is:

$\eta_{2}=\gamma 21 \xi 1 \gamma 22 \xi 2+++\beta 21 \eta 1 \zeta 2$

$\eta_{2}=0.2073+0.1322+0.5928+\zeta 2$

SEM analysis results for the second hypothesis derived structural equation: $\eta 2=0.20730 .1322+0.5928+\xi 2$. The second hypothesis test results show that the entrepreneurial commitment has an influence on the performance of entrepreneurs with a contribution of $35.14 \%$ where the influence of the calculated $\mathrm{T}>\mathrm{T}$ table. The results are consistent with the results of Mustafa (2006) show that the entrepreneurial commitment has a strong influence on the performance of entrepreneurs (business performance). Furthermore Terziovski (2009:58) argues that entrepreneurship is a commitment to a very important factor in achieving the performance and competitiveness. To test the third hypothesis, referring to the equation, namely:

$\eta_{2}=0.2073+0.1322+0.5928+\zeta 2$

Based on these equations, the magnitude of the effect of partial and simultaneous achievement motivation and self efficacy on the performance of an entrepreneur can be seen

in the following table. 
The Entrepreneurship Characteristics in Relation to Improve the Performance of the Small-Scale Seaweed

Tabel 5. Direct Influence of Achievement Motivation and Self Efficacy to Performance of Small-Scale Seaweed Entrepreneurs

\begin{tabular}{ccc}
\hline Latent Variables & Path Coefficient & Direct Influence \\
\hline$\xi_{1}$ & 0,2073 & $4,30 \%$ \\
$\xi_{2}$ & 0,1322 & $1,75 \%$ \\
\hline Simultaneous Influence $\left(\mathbf{R}^{\mathbf{2}}\right)$ & & $6,05 \%$ \\
\hline
\end{tabular}

In the table above, shows that: either partially or simultaneously there is an influence of achievement motivation and self efficacy on the performance of entrepreneurs, where the effect of simultaneous contribution of $6.05 \%$. Thus, it can be stated that: if the achievement motivation and self-efficacy increases, the performance of entrepreneurs tend to increase. Line proposed by Boekaerts et. al., (2002) in which the motivation is not enough to produce a performance if it is not based on faith in the capabilities (self efficacy) can perform the task properly to achieve the expected results.

Furthermore the amount of indirect influence of achievement motivation and self efficacy on performance of seaweed entrepreneurs through entrepreneurial commitment is reduced from the total effect as shown in the following table.

Table 6. Indirect Influence of Achievement Motivation and Self-Efficacy to Seaweed Entrepreneurs Performance of Entrepreneurial Commitment

\begin{tabular}{|c|c|c|c|c|}
\hline Variables & $\begin{array}{c}\text { Path } \\
\text { Coefficient }\end{array}$ & $\mathbf{t}_{\text {hitung }}$ & $\mathbf{t}_{\text {tabel }}$ & $\begin{array}{c}\text { Indirect influence } \\
\text { contribution }\end{array}$ \\
\hline$\xi_{1}$ & $\square_{21}=0,2073$ & & \multirow{6}{*}{1,966} & \multirow{3}{*}{$4,67 \%$} \\
\hline & $\square_{11}=0,3800$ & 6,9241 & & \\
\hline & $\square_{21}=0,5928$ & 7,1063 & & \\
\hline \multirow[t]{3}{*}{$\xi_{2}$} & $\square_{22}=0,1322$ & 2,0989 & & \multirow{3}{*}{$4,02 \%$} \\
\hline & $\square_{12}=0,5131$ & 8,8928 & & \\
\hline & $\square_{21}=0,5928$ & 7,1063 & & \\
\hline \multicolumn{4}{|c|}{ Simultaneous Influence $\left(\mathbf{R}^{2}\right)$} & $8,69 \%$ \\
\hline
\end{tabular}

In the table above, shows the results of hypothesis testing to either partially or four simultaneous achievements motivation and self-efficacy indirectly influence the performance of sesweed entrepreneurs through entrepreneurial commitment. Simultaneously contribute indirectly influence amounted to 8.69\%.

\section{Conclusion}

\section{Conclusions And Policy Implications}

1. The test results through assessment scores of respondents on each dimension of the variables showed that in general each of the dimensions of achievement motivation, self efficacy, entrepreneurial commitment, and performance of small-scale seaweed entrepreneurs in South Sulawesi Province not fully well, where all dimensions are still in the degree sufficient fine. Some of the indicators in each of the variables have the lowest levels. Model estimation results show achievement motivation and self-efficacy significantly influences entrepreneurial commitment, so as to increase the commitment of entrepreneurship is determined by achievement motivation and self efficacy. While the influence of the highest contribution to the commitment of entrepreneurship is partially caused by self-efficacy. This suggests that the strengthening that occurs in more entrepreneurial commitment is dominated by the influence of self-efficacy is contributed by the dimensions of confidence in the capability based experience, planned behavior, and achievement of planned.

2. Model estimation results show significant commitment to the performance of self-employed seaweed entrepreneurs, thus strengthening the performance of seaweed entrepreneurs contributed by the commitment through the strengthening of desire or intention, discipline, and courage.

3. Model estimation results show, achievement motivation and self-efficacy significantly influence the performance of seaweed entrepreneurs. While the highest contribution effect on the performance of an entrepreneur is partially dominated by achievement motivation through the strengthening of achievementoriented, future oriented, enjoy challenges, and tough. 
The Entrepreneurship Characteristics in Relation to Improve the Performance of the Small-Scale Seaweed

4. Model estimation results show, achievement motivation and self-efficacy significantly influence the performance of seaweed entrepreneurs through entrepreneurial commitment. This suggests that the strengthening of performance is affected by the strengthening of the entrepreneurial commitment that contributed entrepreneurship through self-efficacy and achievement motivation seaweed entrepreneur. While the ultimate effect of the partial contribution is dominated by the influence of achievement motivation on the performance of entrepreneurs through a entrepreneurial commitment.

\section{Policy Implications}

Referring to the conclusions of this study, in answering the problems occurred related to the influence of achievement motivation and self-efficacy toward entrepreneurial commitment and its impact on the performance of small-scale seaweed entrepreneurs , made some suggestions as follows:

Recommended for other researchers to develop studies and research in the field of management, especially human resource management from the perspective of entrepreneurship in small businesses related to achievement motivation, self efficacy, entrepreneurial commitment and entrepreneurs performance. Community empowerment through coaching and training activities, the government advised not only oriented towards increasing production and marketing of seaweed but also oriented toward the establishment of the entrepreneurship characteristics through the development of the personality values of continuous and sustained so as to give the effect of learning outcomes.

In addition, it is advisable to build self-efficacy and achievement motivation in the entrepreneurial small-scale seaweed-oriented commitment to strengthening entrepreneurship. In connection with efforts to increase the performance of small-scale seaweed entrepreneurs, then the department of Marine and Fisheries of South Sulawesi province are advised to build achievement motivation, self efficacy, and entrepreneurial commitment.

\section{Daftar Pustaka}

[1] Bandura, A. and Edwin A. Locke. 2003. Negative Self-efficacy and Goal Effects Revisited. Journal of Applied Psychology. Vol. 88 , No. $1,87-99$.

[2] Boekaerts, M., Pintrich, P. R., S-Zeidner, M. 2000. Self-regulation: An introductory overview. In M. Boekaerts, P. R. Pintrich, \& M. Zeidner (Eds.), Handbook of self-regulation (pp. 1-9). San Diego, CA: Academic Press.

[3] Fortune, Anne. E, dan Mingun Lee, Alonzo Cavazos. 2005. Achievement Motivation and Outcome In Social Work Field Education. Washington: Winter 2005. Vol. 41, Iss. 1; pg. 115, 15 pgs

[4] Hair, J.F., Anderson, R.E., Tatham, R.L. \& Black, W.C. 2006. Multivariate Data Analysis (6th ed). Engelwood Cliffs, NJ: Prentice Hall.

[5] Harun Al-Rasyid. 1994. Tehnik Penarikan Sampel dan Penyusunan Skala. Program Pascasarjana Universitas Padjadjaran Bandung.

[6] Mustafa, Rasha, H. A., Colin Wheeler, Marian V. Jones. 2006. Entrepreneurial Orientation, Commitment to The Internet and Export Performance In Small and Medium Sized Exporting Firms. Springer Science+Business Media, Inc.

[7] Sugiyono, 2008. Metode Penelitian Kuantitatif, Kualitatif dan R \& D, Penerbit Alfabeta, Bandung.

[8] Tang, Jintong. 2008. Environmental Munificence For Entrepreneurs: Entrepreneurial Alertness and Commitment. Journal of Entrepreneurial Behaviour \& Research Bradford: 2008. Vol. 14, Iss. 3; pg. 128.

[9] Terziovski, Mile. 2009. Energizing Management through Global Innovation and Entrepreneurship. Edition Published in the Taylor \& Francis e-Library Umar, Husein. 2001. Metode Penelitian Untuk Skripsi dan Tesis Bisnis. PT Raja Grafindo Persada. Jakarta.

[10] Wigfield, Allan and Jacquelynne S. Eccles. 2002. Development of Achievement Motivation. Educational Psychology. 